\title{
ISOLASI DAN UJI AKTIVITAS ANTIDIABETES KULIT BATANG TUMBUHAN
} JELUTUNG (Dyera costulata)

\author{
Arjinal Arjinal, Muhammad Almurdani, Rudi Hendra, Hilwan Yuda Teruna \\ Program Studi Pasca Sarjana Kimia, Fakultas Matematika dan Ilmu Pengetahuan Alam, Universitas Riau, \\ Pekanbaru (28293), Riau, Indonesia \\ "email: hyteruna@lecturer.unri.ac.id
}

Received 6 December 2019

Accepted 22 January 2020

\begin{abstract}
Abstrak
Penelitian ini bertujuan untuk mengetahui aktivitas antidiabetes senyawa dari hasil isolasi ekstrak $n$-heksana dan diklorometana kulit batang jelutung (Dyera costulata). Teknik ekstraksi dilakukan dengan metode maserasi dan tahap isolasi dilakukan dengan metode kromatografi vakum cair. Uji aktivitas antidiabetes dilakukan menggunakan metode penghambatan aktivitas enzim $\alpha$-Glukosidase dengan subtrat $p$-nitrophenyl- $\alpha-D$ glucopyranosida ( $p$-NPG) dengan akarbose sebagai obat standar dan diukur pada panjang gelombang $415 \mathrm{~nm}$. Hasil isolasi yang dilakukan pada ekstrak diklorometana diperoleh senyawa asam benzoat, sedangkan dari ekstrak $n$-heksana didapatkan senyawa lupeol. Hasil uji antidiabetes menunjukkan bahwa asam benzoat memiliki aktivitas sedang dengan nilai IC50 143,259 $\mu \mathrm{g} / \mathrm{mL}$, sedangkan lupeol memiliki aktivitas kuat dengan nilai IC50 42,257 $\mu \mathrm{g} / \mathrm{mL}$ (akarbose IC50 19,734 $\mu \mathrm{g} / \mathrm{mL}$ ). Oleh karena itu, dapat disimpulkan bahwa tumbuhan ini dapat digunakan sebagai obat antidiabetes.
\end{abstract}

Kata kunci: Dyera costulata, Asam Benzoat, Lupeol, Akarbose

Abstract
The purpose of this research was aimed to investigate the antidiabetic activity of the compound from the isolation dichloromethane extracts and $n$-hexane jelutung bark (Dyera costulata). Extraction technique is done by maceration method and isolation stage is done by liquid vacuum chromatography method. Antidiabetic activity test have been carried out used the $\alpha$-glucosidase enzyme activity inhibition method with the substrate $p$-nitrophenyl- $\alpha$-Dglucopyranosida (p-NPG) with rootbose as a standard drug and measured at a wavelength of $415 \mathrm{~nm}$. The results of isolation carried out on dichloromethane extracts obtained benzoic acid compounds, while from $n$-hexane extract obtained lupeol compounds. The results of antidiabetic test showed that benzoic acid had moderate activity with $\mathrm{IC}_{50}$ value 143,6173 $\mu \mathrm{g} / \mathrm{mL}$, whereas lupeol had strong activity with IC $_{50}$ value $43,0016 \mu \mathrm{g} / \mathrm{mL}$ (acarbose IC $_{50}$ $19,734 \mu \mathrm{g} / \mathrm{mL}$ ). Therefore, it can be concluded that this plant can be used as an antidiabetic drug.

Keywords: Dyera costulata, Asam Benzoat, Lupeol, Acarbose

\section{Pendahuluan}

Diabetes mellitus merupakan penyakit yang paling banyak diderita oleh masyarakat Riau. Hal ini dibuktikan dari data Riskersdas tahun 2013 yang melaporkan provinsi Riau berada di urutan nomor tiga tertinggi di Indonesia penderita diabetes mellitus sebesar 1,0 \%.
Peningkatan jumlah penderita diabetes melitus di Indonesia dari tahun ke tahun mengalami kenaikan yang cukup signifikan dimana pada tahun 2007 dengan prevalensi $1,1 \%$ menjadi $2,1 \%$ pada tahun 2013. 
Didalam penatalaksanaan penyakit diabetes, terdapat beberapa program yang dapat dilaksanakan. Salah satu upaya yang dapat dilakukan adalah dengan memperbanyak temuan sumber obat baru dengan pendekatan etnomedisin terhadap tumbuhan obat tradisional yang digunakan oleh suku-suku pedalaman. Salah satu tumbuhan yang sangat bermanfaat bagi penduduk suku pedalaman sebagai tradisional adalah tumbuhan jelutung.

Jelutung merupakan tumbuhan yang berasal dari famili Apocynaceae yang berupa pohon dengan diameter batang kayu sekitar $100 \mathrm{~cm}$ dangan tinggi mencapai 25-45 meter (Martawijaya at al., 2005).

Penelitian sebelumnya telah dilaporkan oleh Kouji et al. (1992), yang meneliti daun D. costulata sebagai penghambat alergi. Penelitian tersebut menggunakan metode passive cutaneus anaphylaxis untuk reaksi alergi tipe 1 yang diuji pada ekstrak dan senyawa murni yang diisolasi dari $D$. costulata. Hasil penelitian diperoleh bahwa ekstrak butanol dari daun D. costulata mampu menghambat alergi sebesar $55 \%$ dan senyawa murni yang didapatkan adalah dimetilinositol mampu menghambat alergi sebesar $34.2 \%$.

Subhadhirasakul at al. (2003), yang meneliti ekstrak kloroform dan $n$-butanol dari daun D. costulata. Hasil penelitian ini diperoleh senyawa $\beta$-amirin dan rhamnazin yang diisolasi dari ekstrak kloroform dan kuersetin-3-O- $\alpha$-Lrhamnopiranosida yang diisolasi dari ekstrak $n$-butanol.

Sejauh ini belum ada yang melaporkan tentang uji antidiabetes dari kulit batang tumbuhan ini. Oleh karena itu, penelitian ini dilakukan untuk mengetahui kandungan metabolit sekunder dan aktivitas antidiabetes dari kulit batang $D$. costulata sehingga dapat memberikan informasi dalam pemanfaatan tumbuhan D. costulata.

\section{Metode Penelitian}

Alat dan bahan

Alat-alat yang digunakan dalam penelitian ini adalah satu set alat destilasi, ultrasonicator (Kery Pulsatron), satu set kromatografi cair vakum, satu set alat HPLC (Shimadzu LC solution), satu set flash chromatography, satu unit rotary evaporator (Buchi R-114), lampu UV model UVL-52(254 dan $366 \mathrm{~nm})$, alat penentu titik leleh Fisher Johns, spektrofotometer UV-Visible (Genesys 10S UV-Vis), spektrofotometer IR (Shimadzu, IR Prestige-21), spektrometer NMR Agilent $500 \mathrm{MHz}$ dan peralatan lain yang umum digunakan sesuai cara kerja.

Sampel yang digunakan dalam penelitian ini adalah kulit batang $D$. costulta diambil dari Kecamatan Kelayang, Kabupaten Indragiri Hulu, Provinsi Riau. Pelarut yang digunakan adalah metanol, etil asetat, n-heksana, diklorometana, dimetil sulfoksida asam sulfat, kloroform, amoniak, reagen penampak noda anisaldehid, pereaksi Dragendorff, pereaksi Mayer, pereaksi Liebermann Burchard, $\mathrm{HCl}$ pekat, larutan besi(III) klorida $1 \%$, aqua DM, pelat KLT silika gel $\mathrm{GF}_{254}$, silika gel $60 \mathrm{GF}_{254}$, silika gel $60 \quad(230-400$ mesh), enzim $\alpha$ glukosidase, akarbose.

\section{Preparasi Sampel}

Kulit batang tumbuhan jelutung dikering anginkan dan dijaga agar tidak terkena sinar matahari secara langsung, kemudian dihaluskan hingga menjadi bubuk yang siap untuk dimaserasi.

\section{Ekstraksi}

Ekstraksi dilakukan dengan metode maserasi. Serbuk kulit batang jelutung sebanyak 3,9 kilogram dimaserasi secara bertingkat dalam botol gelap dengan menggunakan pelarut diklorometana selama 3 hari, kemudian disaring. Proses ekstraksi dilakukan hingga beberapa kali pengulangan sampai hasil penyaringan bening. Maserat yang diperoleh diuapkan pelarutnya menggunakan alat rotary 
evaporator, sehingga didapat ekstrak diklorometana. Selanjutnya diekstraksi dengan pelarut $n$-heksana dengan cara yang sama, sehingga didapatkan ekstrak total heksana. Ekstrak ini kemudian dianalisis menggunakan KLT untuk melihat noda dan perbandingan eluen terbaik untuk menjadi acuan ke tahap isolasi menggunakan VLC.

\section{Uji Antidiabetes}

Uji antidiabetes menggunakan metode penghambatan aktivitas enzim $\alpha$ glukosidase dengan subtrat $p$-nitrophenyl$\alpha$ - $D$-glucopyranosida ( $p$-NPG) oleh Salehi et al. (2013), Sheng et al. (2014) dan Zhang et al. (2016). Sampel di encerkan dengan metode two fold dilution dari konsenrasi 1000 - 31,25 $\mu \mathrm{g} / \mathrm{mL}$. Sebanyak $10 \mu \mathrm{L}$ DMSO $\left(\mathrm{B}_{0}\right)$ dan $10 \mu \mathrm{L}$ sampel $\left(\mathrm{S}_{0}\right)$ ditambah dengan $50 \mu \mathrm{L}$ buffer fosfat $\mathrm{pH}$, $25 \mu \mathrm{L} p$-NPG $20 \mathrm{mMserta10} \mu \mathrm{L}$ DMSO $\left(\mathrm{B}_{1}\right)$ dan $10 \mu \mathrm{L}$ sampel $\left(\mathrm{S}_{1}\right)$ dengan $50 \mu \mathrm{L}$ buffer fosfat $\mathrm{pH} 7,25 \mu \mathrm{L} p$-NPG $20 \mathrm{mM}$ dan $25 \quad \mu \mathrm{L} \quad \alpha$-Glucosidase 0,2 $\mathrm{U} / \mathrm{mLdicampur}$ di dalammicroplate 96well dan diinkubasi selama 30 menit pada suhu $37{ }^{0} \mathrm{C}$. Reaksi dihentikan dengan penambahan $100 \mu \mathrm{L} \quad \mathrm{Na}_{2} \mathrm{CO}_{3} \quad 0,1 \quad \mathrm{M}$, selanjutnya absorbansi diukur dengan microplate reader pada panjang gelombang $415 \mathrm{~nm}$. Hal yang sama juga dilakukan pada kontrol positif akarbose dengan konsentrasi two fold dilution 100 $3,125 \mu \mathrm{g} / \mathrm{mL}$. Nilai \% inhibisi dapat dihitung dengan rumus sebagai berikut:

$$
\% \text { Inhibisi }=\frac{\left(\mathrm{B}_{1}-\mathrm{B}_{0}\right)-\left(\mathrm{S}_{1}-\mathrm{S}_{0}\right)}{\left(\mathrm{B}_{1}-\mathrm{B}_{0}\right)} \times 100
$$

Keterangan:

$\left(\mathrm{B}_{1}-\mathrm{B}_{0}\right)=$ Absorbansi tidak mengandung sampel

$\left(\mathrm{S}_{1}-\mathrm{S}_{0}\right) \quad=$ Absorbansi sampel

Nilai $\mathrm{IC}_{50}$ dihitung menggunakan persamaan logaritma $(\mathrm{Y}=\mathrm{a} \ln \mathrm{X}+\mathrm{b})$ dari kurva kalibrasi dengan memplotkan konsentrasi sampel vs nilai \% inhibisi.

\section{Hasil Dan Pembahasan}

Isolasi Senyawa

Hasil isolasi yang diperoleh dari kulit batang jelutung ekstrak diklorometana adalah adalah kristal bewarna kuning kecoklatan yaitu pada fraksi DC-D-01.

Spektroskopi inframerah dari DC-D-01 memperlihatkan adanya serapan maksimum pada bilangan gelombang 3070 $\mathrm{cm}^{-1}$ yang mengindikasikan adanya gugus $\mathrm{O}-\mathrm{H}$, pada 2950, 2881 dan $2878 \mathrm{~cm}^{-1}$ yang mengindikasikan adanya gugus $\mathrm{C}-\mathrm{H}$, pada 1697 mengindikasikan adanya gugus $\mathrm{C}=\mathrm{O}$, dan pada $1584 \mathrm{~cm}^{-1}$ yang mengindikasikan adanya gugus $\mathrm{C}=\mathrm{C}$. Analisis spektrum ${ }^{1} \mathrm{H}$ NMR memperlihatkan pergeseran kimia pada $\delta \mathrm{H} 8,15 \mathrm{ppm}(1 \mathrm{H}, d=5 \mathrm{~Hz}), \quad 7,64$ ppm $(1 \mathrm{~h}, d d=5 \mathrm{~Hz}), 7,50(1 \mathrm{H}, d)$.

Sehingga senyawa ini diperkirakan sebagai Asam benzoat.

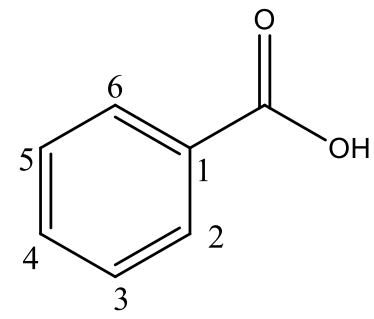

Gambar 1. Asam Benzoat

Hasil isolasi yang diperoleh dari kulit batang jelutung ekstrak n-heksana berupa kristal putih yaitu pada fraksi DC-H-01. Analisis inframerah senyawa DC-H-01 menunjukkan adanya serapan maksimum pada bilangan gelombang $3286 \mathrm{~cm}^{-1}$ yang mengindikasikan adanya gugus $\mathrm{O}-\mathrm{H}$, pada 2946, $2856 \mathrm{~cm}^{-1}$ yang mengindikasikan adanya gugus $\mathrm{C}-\mathrm{H}$ alifatik, pada 1637 mengindikasikan adanya gugus $\mathrm{C}=\mathrm{C}$, dan pada $1188 \mathrm{~cm}^{-1}$ yang mengindikasikan adanya gugus $\mathrm{C}-\mathrm{O}$. Analisis spektrum ${ }^{1} \mathrm{H}$ NMR dari senyawa DC-H-01 menunjukkan sinyal pada daerah $\delta \mathrm{H} \mathrm{4,68}$ dan 4,56 $(1 \mathrm{H}, \mathrm{s})$ diduga merupakan sinyal dari proton metilen yang terikat pada $\mathrm{C}$ kwartener sehingga muncul sebagai puncak singlet. 
Selanjutnya terlihat adanya sinyal untuk proton metin pada $\delta \mathrm{H} \mathrm{3,20}(1 \mathrm{H}, \mathrm{m})$ yang diduga merupakan proton metin yang terikat pada $\mathrm{C}$ yang mengikat $\mathrm{OH}$ yang terkopling dengan dua proton tetangganya dan juga terkopling dengan proton dari gugus $\mathrm{OH}$ sehingga muncul sebagai puncak multiplet. Sinyal ini khas untuk triterpenoid yang mengikat $\mathrm{OH}$ pada posisi C-3. Sinyal pada $\delta H ~ 0,77 ; 0,80 ; 0,84 ; 0,96$; 0,$98 ; 1,04$ dan 1,69 yang merupakan khas dari proton metil senyawa triterpenoid. Senyawa DC-H-01 diduga senyawa lupeol

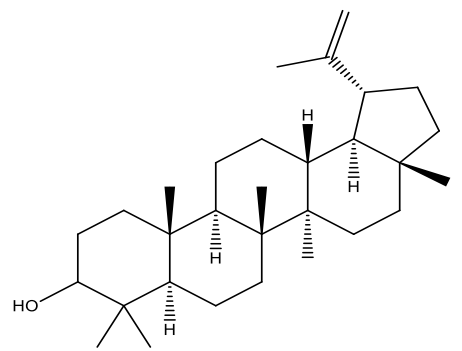

Gambar 2. Lupeol

\section{Aktivitas antidiabetes}

Uji antidiabetes dilakukan pada senyawa asam benzoat dan lupeol dengan metode penghambatan $\alpha$-glukosidase (in vitro) dengan p-nitrophenyl- $\alpha$-Dglucopyranoside (p-NPG). Reaksi diakhiri dengan penambahan $100 \mu \mathrm{L} \mathrm{Na2CO3} \mathrm{0,1}$ M. Kemudian, absorbansi diukur dengan pembaca plat 96-sumur. Asam benzoat menunjukkan aktivitas enzim $\alpha$ glukosidase dengan nilai $\mathrm{IC}_{50} \quad 143,6173$ $\mu \mathrm{g} / \mathrm{mL}$. Sedangkan aktivitas senyawa lupeol dengan nilai $\mathrm{IC}_{50} 43,0016 \mu \mathrm{g} / \mathrm{mL}$. Tabel 1

Penelitian penghambatan enzim $\alpha$ glukosidase terhadap senyawa asam benzoat dan lupeol belum pernah dilaporkan sebelumnya.

Tabel 1. Nilai $\mathrm{IC}_{50}$ senyawa hasil isolasi dari kulit batang $D$. costulata

\begin{tabular}{cc}
\hline Sample & IC50 $(\mathbf{p p m})$ \\
\hline Asam Benzoat & $143,259 \pm 0,327$ \\
Lupeol & $42,136 \pm 0,157$ \\
Akarbose & $0,974 \pm 0,342$ \\
\hline
\end{tabular}

\section{Kesimpulan}

Berdasarkan hasil penelitian dapat disimpulkan bahwa kulit batang D.costulata mengandung senyawa asam benzoat dan lupeol. Uji aktivitas antidiabetes dari senyawa asam benzoat menunjukkan nilai $\mathrm{IC}_{50} \quad 143,259 \pm 0,327$, sedang sedangkan aktivitas antidiabetes dari senyawa lupeol menunjukkan hasil $\mathrm{IC}_{50} 42,136 \pm 0,157$.

\section{Daftar Pustaka}

Kouji, S., Hosomi, K., Arakawa, T., Uzawa, M., Ito, H., Saburi, Y.. 1992. Isolation and Characterization of an Allergy Inhibitor from the Jelutong, Dyera costulata Hook. f., Bioscience, Biotechnology, and Biochemistry, 56(6): 975-975

\section{Ucapan Terima Kasih}

Terima kasih kepada hibah penelitian tim pascasarjana KEMENRISTEKDIKTI tahun anggaran 2018 yang telah membiayai penelitian ini dengan kontrak Nomor: 339/UN.19.5.1.3/PP/2018, tanggal 19 Februari 2018.

Martawijaya, A., Kartasujana, I.,Kadir, K., Prawira, S.A., 2005, Atlas Kayu Indonesia jilid I, Badan Penelitian dan Pengembangan Departemen kehutanan,Bogor

Riset Kesehatan Dasar (Riskerdas) 2013 .Badan Penelitian Dan 
Pengembangan Kesehatan

Kementerian Kesehatan RI Tahun 2013. p: 87- 89.

Salehi, P., Asghari, B., Esmaeili, M. A., Dehghan, H., and Ghazi, I., 2013. $\alpha$ -Glucosidase and $\alpha$-amylase inhibitory effect and antioxidant activity of ten plant extracts traditionally used in Iran for diabetes. Journal of Medicinal Plants Research, 7(6), 257-266.

Sheng, Z., Dai, H., Pan, S., Wang, H., $\mathrm{Hu}, \mathrm{Y}$. , and Ma, W., (2014). Isolation and Characterization of an $\alpha$-Glucosidase Inhibitor from Musa spp. (Baxijiao) Flowers. Molecules, 19, 10563-10573.

Subhadirasakul, S., Jankeaw B, Malinee A., 2003. Chemical constituent and antioxidative activity of the extracts from Dyera costulata leaves. J. Sci. Technol. 25(3): 351-357.

Zhang, L., Tu, Z., Yuan, T., Wang, H., Xie, X., and Fu, Z., (2016). Antioxidants and $\alpha$-glucosidase inhibitors from Ipomoea batatas leaves identified by bioassay-guided approach and structure-activity relationships. Food Chemistry, 208, 61-67. 